\title{
Announcements
}

(C) Springer Nature B.V. 2018

AIOSP_Association Internationale d'Orientation Scolaire et Professionnelle IAEVG-International Association for Educational and Vocational Guidance IVBBB-Internationale Vereinigung für Bildungs- und Berufsberatung AIOEP-Asociación Internacional para la Orientación Educative Y Profesional

\section{What is IAEVG ?}

The International Association for Educational and Vocational Guidance (IAEVG) is the worldwide counsellors' association and represents individuals as well as national and regional associations concerned with educational and vocational guidance on all continents. 


\section{The mission of IAEVG}

The aims of educational and vocational guidance are to assist students and adults in making their personal decisions about learning and work. This is achieved by helping people to:

- understand and appreciate their skills and abilities

- relate effectively with others

- explore career alternatives

- develop appropriate plans for educational and career management

- promote better vocational qualifications at all levels

- contribute to equal access for girls and women in education and work

- integrate successfully in society and the labour market

\section{The objectives of the Association are:}

- to promote and improve communication between people and organizations active in educational and vocational guidance

- to encourage the continuing professional development of ideas, practice and research in the field of guidance and counselling

- to collect and disseminate information on the latest educational and vocational guidance practice, study and research

\section{Benefits of Membership of IAEVG}

As a member of IAEVG, you:

- belong to the only international association for careers and educational guidance practitioners and institutions

- will be sent three informative newsletters annually, published in English, French, Spanish and German

- access three editions of the refereed International Journal for Educational and Vocational Guidance

- have the opportunity to submit articles for publication in the professional journal and worldwide distribution

- can participate in international careers and guidance conferences around the world, learning about best practices, exchanging innovative ideas and building a rich international network

- can exercise your right to vote at the 4-yearly General Assembly of IAEVG

- become involved in special projects and/or interest groups

- can stand for election for a leadership position in the Association 


\title{
How to become a member?
}

To become a member of IAEVG, or renew your membership, simply contact the IAEVG Administration Centre (E-mail: membership@iaevg.org; Tel: +613 729 6164) or visit www.iaevg.org/IAEVG/. Print the Membership Application Form and Instructions for Payment.

Complete the Form and submit it by fax or mail to the IAEVG Administration Centre

There are many payment options available:

- You may pay in any of four currencies (US dollars, Euro, Great Britain Pounds or Canadian Dollars) or you may pay by VISA, Mastercard, Bank Transfer, International Postal Money Order or Cheque

- For individuals the rates for 2016 are: \$91 US Dollars or €75 Euro or $£ 59$ Great Britain Pounds or $\$ 110$ Canadian Dollars

- Rates for Associations/Institutions vary according to the number of members. A table outlining the full schedule of fees is included in the Membership Application Form and Instructions for Payment (see website).

\section{Contacts}

\author{
Membership Administration \\ IAEVG Administration Centre \\ c/o Canadian Career Development Foundation \\ 119 Ross Avenue, Suite 202 \\ Ottawa, Ontario K1Y 0N6, Canada \\ E-mail : membership@iaevg.org \\ Tel: 1-877-729-6164, Tel: (613) 729-6164
}

IAEVG Website: www.iaevg.org

\section{Officers and Board of Directors}

Présidente

Präsident

Presidente 
Secretary General

Laurent Matte, Canada

Secrétaire général

Generalsekretärin

Secretario general

Treasurer

Beatriz Malik, Spain

Trésorière

Schatzmeister

Tesorero

Board of Directors

Comité Exécutif

Exekutivausschuß

Junta Directiva

\author{
Bill Borgen, Canada \\ Tibor Bors Borbély-Pecze, Hungary \\ Gabriela Cabrera Lopez, Mexico \\ Jane Goodman, USA \\ Mary McMahon, Australia \\ Gert Van Brussel, The Netherlands \\ Peter Weber, Germany
}

\section{Conferences}

IAEVG, Gothenberg, Sweden

October 2-4, 2018

“A Need for Change"

The conference is jointly organized with the Swedish Association of Guidance Counsellors, in association with the City of Gothenburg Career Guidance Centre.

The meeting will take place over three days and will offer key note addresses and expert panels, several international symposia, poster presentations and workshops. The goals of the meeting are to analyze and discuss the approaches and contributions of Educational and Vocational Guidance, public and institutional policies and their relationship with current demands in today's world; to discuss the challenges that affect daily life and the educational and professional trajectories of young people; and to promote the construction of new strategies and interventions across different levels of education that will prepare the new generations for social change and transformation with a sense of responsibility and ethical commitment.

This international conference, like those preceding it, demonstrates the vitality, dynamism and initiative that prevail in IAEVG. In addition to the scientific program, there are opportunities to network and share experiences with colleagues from around the world.

This year's conference theme, "a need for change" will focus on five areas:

I. A need for change in delivery and/or access to career guidance and counselling

What is needed to make the Lifelong Guidance a reality for everyone?

II. A need for change in the training of career guidance professionals The needs for delivery of Lifelong Guidance in a multicultural society 
III. New theories, models and strategies in career guidance and counselling for migrants and refugees

The society is becoming more and more multicultural but still most of our theories and models are based in a western context. What changes do we need for the future?

IV. The role of ICT and social media in career guidance and counselling Especially young people live their lives on social media today - but where do the career guidance and counselling take place?

V. Career guidance and counselling and the ever-changing labour market and access to work

We are supporting young people preparing for occupations and a labour market that still does not exist. At the same time, the working population should be prepared for a changing working life.

Abstract submissions: Closed March 31, 2018

Information

Email: info@iaevgconference2018.se

Website http://www.iaevgconference2018.se/ 